RANCANG BANGUN MEDIA PEMBELAJARAN BLENDED LEARNING BERBASIS WEBSITE DI SMK KP GAJAHMADA 1 METRO

JURNAL

Diajukan Sebagai Salah Satu Syarat Mencapai Gelar SARJANA KOMPUTER

Program Studi Teknik Informatika

STMIK Dharma Wacana Metro

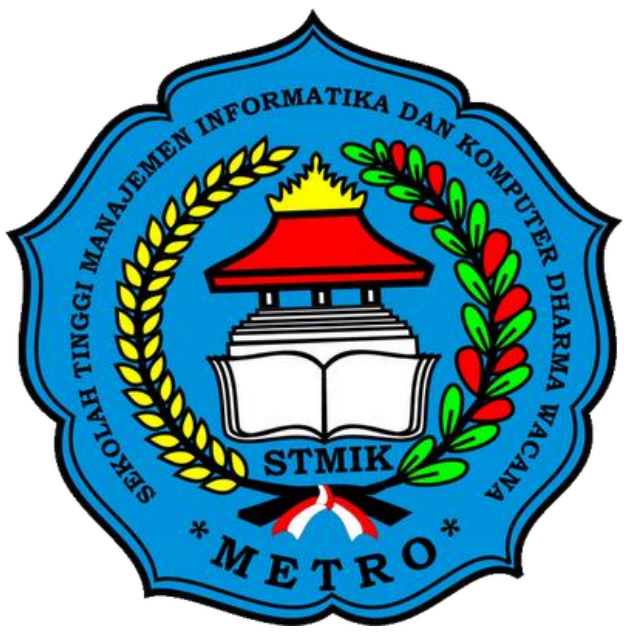

Disusun Oleh

AHMAD ZAKI

15010033

PROGRAM STUDI TEKNIK INFORMATIKA

SEKOLAH TINGGI MANAJEMEN INFORMATIKA DAN KOMPUTER DHARMA WACANA METRO 


\title{
RANCANG BANGUN MEDIA PEMBELAJARAN BLENDED LEARNING BERBASIS WEBSITE DI SMK KP GAJAHMADA 1 METRO
}

\author{
Ahmad Zaki ${ }^{1}$, Heri Nurdianto, S.Kom., M.T.I ${ }^{2}$, M. Reza Redo Islami, S.Kom.,M.TI ${ }^{3}$ \\ ${ }^{1}$ Program Studi Teknik Informatika, STMIK Dharma Wacana Metro \\ ${ }^{2}$ Dosen TetapTeknik Informatika, STMIK Dharma Wacana Metro \\ Jalan Kenanga No.3, Mulyojati 16C Kota Metro \\ Email : Princez4k1@gmail.com
}

\begin{abstract}
Abstrak
SMK KP Gajahmada 1 Metro merupakan salah satu lembaga pendidikan kejuruan yang memiliki tugas untuk mempersiapkan peserta didiknya untuk dapat bekerja di bidang-bidang tertentu. Sistem pembelajaran yang berjalan saat ini menggunakan metode konvensional dimana kegiatan belajar mengajar berlangung secara tatap muka dengan ceramah dan mencatat, proses pembelajaran berjalan sangat abstrak dan teoritis serta kebenaran bersifat absolut dari guru dimana hal ini menyebabkan siswa kurang aktif, siswa kurang mengerti isi dari materi yang disampaikan serta guru mengalami kesulitan dalam pembagian materi ke seluruh siswa. Proses pembelajaran tidak terlepas dari peran media pembelajaran yang bertujuan untuk menyampaikan pesan ,merangsang fikiran, perasaan serta kemauan siswa dalam proses pembelajaran, maka dilakukan penelitian dengan tujuan untuk membuat aplikasi media pembelajaran blended learning berbasis website. Metode blended learning memadukan antara pertemuan tatap muka dengan materi online secara otomatis dengan memanfaatkan teknologi IT (media video conference, phone conference, chating online dan lain-lain).Dengan menggunakan aplikasi ini diharapkan siswa dapat lebih aktif belajar,leluasa dalam bertanya, melakukan konsultasi, menyatakan pendapatnya mengenai materi baik di sekolah maupun diluar jam sekolah dan pembagian materi keseluruh siswa terpenuhi.
\end{abstract}

Kata Kunci: Pembelajaran Konvensional, Media Pembelajaran, Metode Blended Learning

\section{PENDAHULUAN}

Proses pembelajaran tidak terlepas dari peran media pembelajaran yang bertujuan untuk menyampaikan pesan, merangsang fikiran, perasaan serta kemauan siswa dalam proses pembelajaran. Seiring dengan perkembangan Teknologi Informasi (TI) yang semakin pesat, kebutuhan akan suatu konsep dan mekanisme belajar mengajar (pendidikan) berbasis TI menjadi tidak terelakkan lagi.Konsep yang kemudian terkenal dengan sebutan e-Learning ini membawa pengaruh terjadinya proses transformasi pendidikan konvensional ke dalam bentuk digital, baik secara isi(contents) dan sistemnya

Berdasarkan observasi awal di SMK KP Gajahmada 1 Metro, diperoleh informasi bahwa metode pembelajaran yang digunakan masih menggunakan metode pembelajaran konvensional. Pada metode pembelajaran konvensional, guru berperan sebagai pemindah informasi kepada siswa, dan siswa sebagai pendengar yang bersifat pasif selama proses pembelajaran berlangsung. Sebagai 
media pemindah informasi digunakan metode ceramah, contoh dan latihan soal. Proses pembelajaran berjalan sangat abstrak dan teoritis serta kebenaran bersifat absolut dari guru dimana hal ini menyebabkan siswa kurang mendapatkan kesempatan untuk menyatakan pendapatnya, guru cenderung hanya memperhatikan siswa yang dianggap mampu menerima materi yang disampaikan. Padahal setiap siswa berhak mendapatkan perhatian dari guru dan tidak semua siswa memiliki cara belajar terbaik dengan hanya mendengarkan. Hal tersebut menyebabkan guru kesulitan untuk menjaga siswa tetap tertarik dengan materi yang disampaikan dan siswa kurang mengerti isi dari materi yang disampaikan serta guru mengalami kesulitan dalam pembagian materi ke seluruh siswa. Keadaan tersebut memberikan dampak yang sangat besar terhadap rendahnya prestasi belajar siswa.

Dengan metode Blended Learning yang memadukan antara pertemuan tatap muka dengan materi online secara otomatis (e-learning) dengan memanfaatkan teknologi IT (media video conference, phone conference, chating online dan lain-lain). Dengan menggunakan aplikasi yang berpedoman pada metode blended learning siswa dapat leluasa dalam bertanya, melakukan konsultasi, dan menyatakan pendapatnya mengenai materi baik di sekolah maupun diluar jam sekolah. Sehingga setiap siswa merasa memiliki kedekatan langsung dengan guru yang berdampak terhadap meningkatnya prestasi siswa.

\section{METODE PENELITIAN}

Object Oriented Software Enginering (OOSE) diperkenalkan oleh Ivar Jacobson pada tahun 1992 dimana OOSE merupakan versi sederhana dari metode berorientasi objek . Sudut pandang atau fokus di tekankan pada "use case", yaitu deskripsi atau skenario menggambarkan bagaimana pemakai berinteraksi dengan produk atau sistem yang akan dikembangkan. OOSE memiliki 3 tahapan utama yaitu Analysis (Requirement Model \& Analysis Model), Construction (Design Model \& Implementation Model) dan Testing (Test Model).

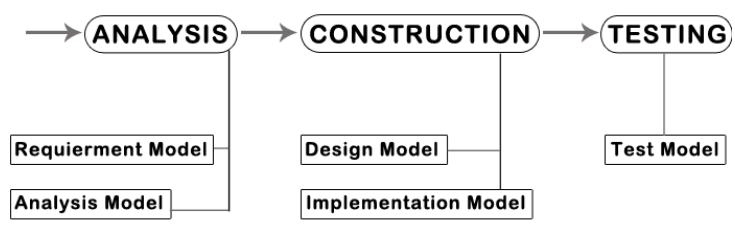

\section{Gambar Metode OOSE}

\section{Requirement Model}

Tahapan untuk mencari kebutuhan pengguna (user requirement) serta identifikasi dan deskripsi pemakai sistem (user) dengan menggambarkan aktor (admin, guru dan siswa) dan use case serta asosiasi antar use case.

\section{Analysis Model}

Tahapan ini digunakan untuk menganalisa datadata yang telah diperoleh (hasil observasi, wawancara dan studi literatur) untuk mengetahui kebutuhan sistem (Hardware dan Sofware yang digunakan) kemudian menentukan objek-objek yang diperlukan dengan menggunakan class diagram

\section{Design Model}

Tahapan ini digunakan untuk memperbaiki model analysis dan menyesuaikan dengan lingkungan implementasi serta menampilkan objek dan operasi semantik sehingga dapat 
dibuat Database Management System (DBMS)

dengan menggunakan sequnce diagram, rancangan input dan output (user interface).

\section{Implementation Model}

Tahapan coding ini untuk menginplementasikan dari tahapan analysis model dan design model. Proses coding disini menggunakan HTML5 dan php untuk sebagai script kode aplikasi ,mysql dengan php MyAdmin untuk memasukan databaseserta tampilan aplikasi setelah selesai baik dari sisi user guru, siswa dan admin.

\section{Test Model}

Tahapan ini merupakan hasil dari pengujian model implementasi. Metode pengujian menggunakan Black Box Testing yang berfungsi untuk mendeteksi kesalahan interface, fungsi yang tidak benar atau tidak ada, kesalahan struktur data dan akses basis data dan kesalahan performasi.

\subsection{Requirement Model}

\section{A. Kebutuhan Pengguna}

Kebutuhan pengguna berguna untuk mengidentifikasi Kebutuhan Fungsional dan Kebutuhan Non Fungsional suatu sistem. Berikut adalah kebutuhan fungsional pada aplikasi media pembelajaran blended learning.

1. Sistem dapat menampilkan materi dalam bentuk teks power point (ppt).

2. Sistem dapat menampilkan video tutorial sebagai media untuk menjelaskan materi.

3. Sistem dapat menampilkan soal-soal latihan
4. Sistem dapat menampilkan forum diskusi

5. User guru dapat mengupload materi, video dan soal latihan

6. User guru dapat melihat progres belajar siswa pada sistem.

Sedangkan Kebutuhan Non Fungsional (Non Functional Requirement) dari aplikasi media pembelajaran blended learning antara lain.

1. Sistem bersifat mudah dipahami (user friendly)

2. Mampu berjalan di semua web browser

3. Memiliki tampilan yang responsive

\section{B. Usecase Daigram}

\section{Gambar Usecase Diagram}

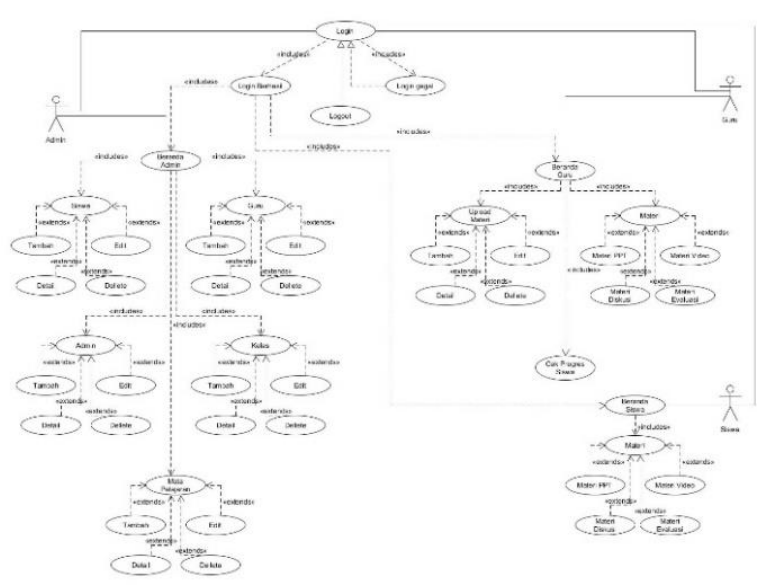

Table Usecase Glossary

\begin{tabular}{|l|l|l|l|}
\hline No. & $\begin{array}{c}\text { Usecase } \\
\text { Name }\end{array}$ & \multicolumn{1}{|c|}{ Description } & Actor \\
\hline 1. & Login & $\begin{array}{l}\text { Use case login ini } \\
\text { berfungsi sebagai } \\
\text { sarana untuk } \\
\text { masuk kedalam } \\
\text { berbagai sistem } \\
\text { dalam sebuah } \\
\text { program dan } \\
\text { sebagai kunci } \\
\text { untuk beberapa } \\
\text { use case yang } \\
\text { mengharuskan use } \\
\text { case ini dilakukan. }\end{array}$ & $\begin{array}{l}\text { Guru, } \\
\text { Siswa }\end{array}$ \\
\hline 2. & $\begin{array}{l}\text { Beranda } \\
\text { Admin }\end{array}$ & $\begin{array}{l}\text { Use case ini } \\
\text { menampilkan fitur }\end{array}$ & Admin \\
\hline
\end{tabular}




\begin{tabular}{|c|c|c|c|}
\hline & & $\begin{array}{l}\text { fitur yang ada } \\
\text { pada user admin }\end{array}$ & \\
\hline 3. & Siswa & $\begin{array}{l}\text { Use case ini } \\
\text { berfungsi untuk } \\
\text { menapilkan } \\
\text { profile siswa. } \\
\text { Terdapat } 4 \text { use } \\
\text { case yang terkait } \\
\text { dalam use case } \\
\text { ini. Yaitu (tambah } \\
\text { siswa, detail, edit, } \\
\text { dan delete ) }\end{array}$ & Admin \\
\hline 4. & Guru & $\begin{array}{l}\text { Use case ini } \\
\text { berfungsi untuk } \\
\text { menapilkan } \\
\text { profile siswa. } \\
\text { Terdapat } 4 \text { use } \\
\text { case yang terkait } \\
\text { dalam use case } \\
\text { ini. Yaitu (tambah } \\
\text { siswa, detail, edit, } \\
\text { dan delete ) }\end{array}$ & Admin \\
\hline 5. & Kelas & $\begin{array}{l}\text { Use case ini } \\
\text { berfungsi untuk } \\
\text { Menambahkan } \\
\text { ruang kelas yang } \\
\text { ada, terdapat } 4 \text { use } \\
\text { case dalam use } \\
\text { case ini, yaitu } \\
\text { (tambah } \\
\text { kelas,detail, edit, } \\
\text { dan delete) }\end{array}$ & Admin \\
\hline 6. & $\begin{array}{l}\text { Mata } \\
\text { Pelajaran }\end{array}$ & $\begin{array}{l}\text { Use case ini } \\
\text { berfungsi untuk } \\
\text { menambahkan } \\
\text { matapelajaran } \\
\text { yang ada. } \\
\text { Terdapat } 3 \text { use } \\
\text { case dalam use } \\
\text { case ini. Yaitu } \\
\text { (tambah maple, } \\
\text { edit, dan delete) }\end{array}$ & Admin \\
\hline 7. & $\begin{array}{l}\text { Beranda } \\
\text { Guru }\end{array}$ & $\begin{array}{l}\text { Use case ini } \\
\text { menampilkan fitur } \\
\text { fitur yang ada } \\
\text { pada user guru }\end{array}$ & Guru \\
\hline 8. & $\begin{array}{l}\text { Upload } \\
\text { Materi }\end{array}$ & $\begin{array}{l}\text { Use case ini } \\
\text { berfungsi untuk } \\
\text { menambahkan } \\
\text { materi pelajaran } \\
\text { sesuai } \\
\text { dengan actor guru } \\
\text { nya masing- } \\
\text { masing. Terdapat } \\
4 \text { use case dalam } \\
\text { use case ini yaitu } \\
\text { (tambah materi, } \\
\text { detail, edit, dan } \\
\text { delete) }\end{array}$ & Guru \\
\hline
\end{tabular}

\begin{tabular}{|c|c|c|c|}
\hline 9. & Materi & $\begin{array}{l}\text { Use case ini } \\
\text { berfungsi untuk } \\
\text { menampilkan } \\
\text { materi yang telah } \\
\text { terupload } \\
\text { berdasarkan kelas } \\
\text { dan mata } \\
\text { pelajaran, terdapat } \\
4 \text { use case dalam } \\
\text { use case ini. Yaitu } \\
\text { (Materi PPT, } \\
\text { Materi Video, } \\
\text { Materi Diskusi, } \\
\text { Materi Evaluasi) }\end{array}$ & Guru \\
\hline 10. & $\begin{array}{l}\text { Cek } \\
\text { Progres } \\
\text { Siswa }\end{array}$ & $\begin{array}{l}\text { Use case ini } \\
\text { menampilkan } \\
\text { progres belajar } \\
\text { siswa dari } \\
\text { mengakses materi }\end{array}$ & Guru \\
\hline 11. & $\begin{array}{l}\text { Beranda } \\
\text { Siswa }\end{array}$ & $\begin{array}{l}\text { Use case ini } \\
\text { berfungsi untuk } \\
\text { menampilkan } \\
\text { pilihan kelas dan } \\
\text { mata pelajaran } \\
\text { yang akan di akses }\end{array}$ & Siswa \\
\hline 12. & Materi & $\begin{array}{l}\text { Use case ini } \\
\text { berfungsi untuk } \\
\text { menampilkan } \\
\text { materi yang telah } \\
\text { terupload } \\
\text { berdasarkan kelas } \\
\text { dan mata } \\
\text { pelajaran, terdapat } \\
4 \text { use case dalam } \\
\text { use case ini. Yaitu } \\
\text { (Materi PPT, } \\
\text { Materi Video, } \\
\text { Materi Diskusi, } \\
\text { Materi Evaluasi) }\end{array}$ & Siswa \\
\hline 13. & Logout & $\begin{array}{l}\text { Use case ini } \\
\text { memungkinkan } \\
\text { actor untuk keluar } \\
\text { dari siste }\end{array}$ & $\begin{array}{l}\text { Admin, } \\
\text { Guru } \\
\text { dan } \\
\text { Siswa }\end{array}$ \\
\hline
\end{tabular}

\subsection{Analysis Model}

Berdasarkan hasil study literatur, solusi yang ditawarkan untuk permasalahan yang ada adalah dengan membangun aplikasi media pembelajaran yang berpedoman pada metode pembelajaran blended learning dimana metode ini memadukan antara pertemuan tatap muka dengan dengan materi online secara 
otomatis dengan memanfaatkan teknologi

IT(media video conference, phone conference, chating online dan lain-lain).

Tabel Kebutuhan Hardware

\begin{tabular}{|l|l|}
\hline \multicolumn{1}{|c|}{$\begin{array}{l}\text { Perangkat } \\
\text { Hardware }\end{array}$} & \multicolumn{1}{|c|}{ Spesifikasi } \\
\hline Laptop & Acer Aspire 4752 \\
\hline Processor & $\begin{array}{l}\text { Intel (R) core (TM) i5- } \\
2410 \mathrm{M} \text { CPU @ } \\
2.30 \mathrm{Ghz} 2.30 \mathrm{Ghz}\end{array}$ \\
\hline Memory & $4.00 \mathrm{~GB}$ \\
\hline Hardisk & $500 \mathrm{~GB}$ \\
\hline VGA & Intel (R) HD Graphics \\
& 3000 \\
\hline Mouses & Havic \\
\hline Smartphone & Infinix Hot 4 \\
\hline Display & 5.5 Inches, 720 x 1280 \\
Smartphone & pixel \\
\hline Android OS & $\begin{array}{l}\text { Android OS, 6.0 } \\
\text { (Marshmallow), With }\end{array}$ \\
& XOS \\
\hline
\end{tabular}

Tabel Kebutuhan Software

\begin{tabular}{|l|l|}
\hline \multicolumn{1}{|c|}{$\begin{array}{c}\text { Perangkat } \\
\text { Software }\end{array}$} & \multicolumn{1}{c|}{ Spesifikasi } \\
\hline Sistem Operasi & Windows 7 Ultimate \\
\hline $\begin{array}{l}\text { Bahasa } \\
\text { Pemrograman }\end{array}$ & PHP \\
\hline Server & XAMPP \\
\hline Database & MySQL \\
\hline $\begin{array}{l}\text { Android } \\
\text { Packager }\end{array}$ & Website2APK \\
\hline
\end{tabular}

Class Diagram

Class Diagram digunakan untuk menentukan objekobjek yang diperlukan dalam pembangunan aplikasi media pembelajaran blended learning.

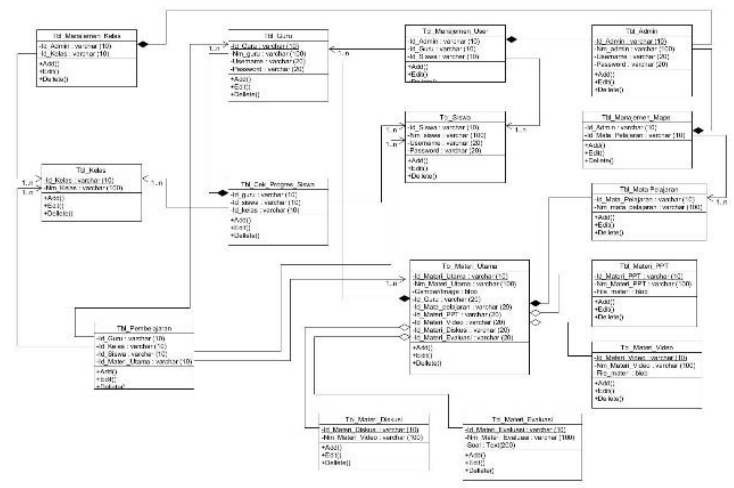

Gambar Class Diagram

\subsection{Design Model}

a. Rancangan Input Output (User Interface) User Interface adalah merupakan mekanisme komunikasi antara pengguna (user) dengan sistem.

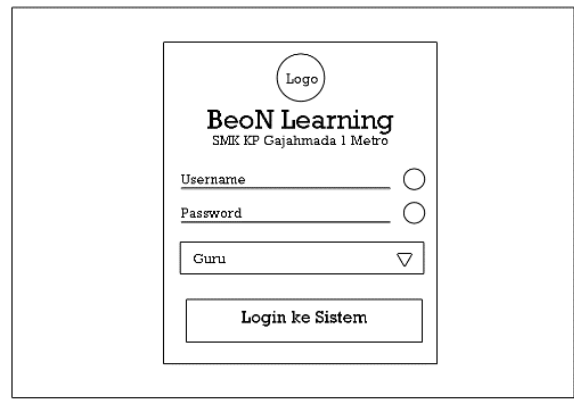

Rancangan Tampilan Login

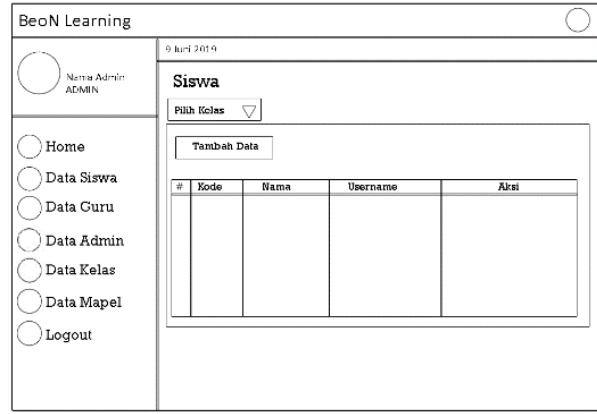

Rancangan Tampilan Daftar Siswa

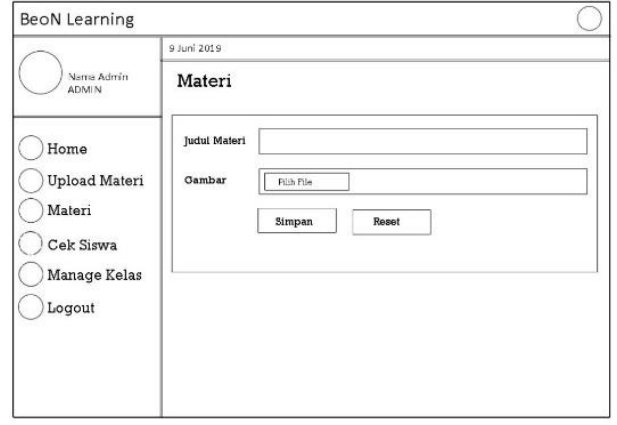

Rancangan Tampilan Upload Materi

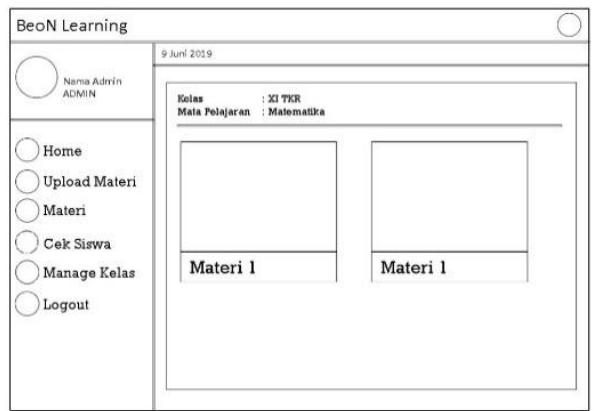


RancanganTampilan Materi Utama

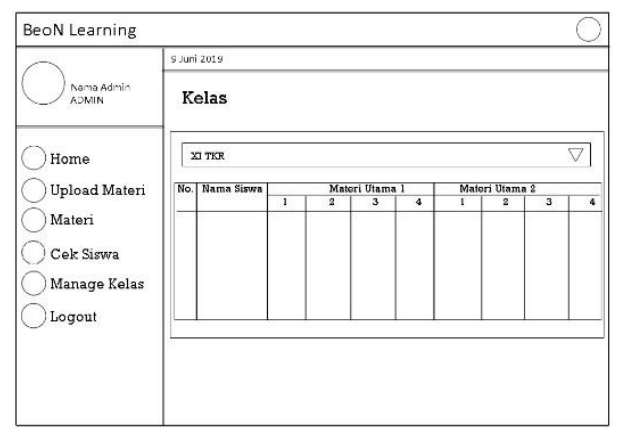

. Rancangan Tampilan Cek Progres Siswa

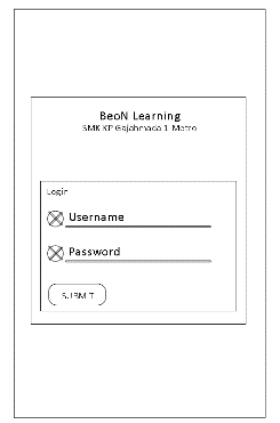

RancanganTampilan Login Siswa

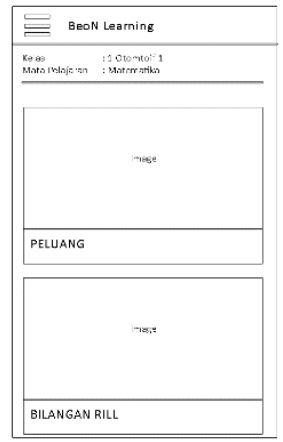

Rancangan Tampilan Materi Utama Siswa

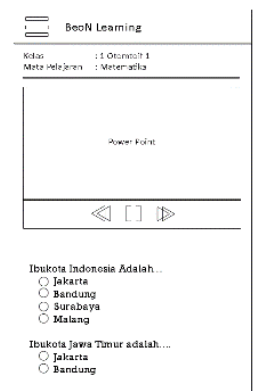

RancanganTampilan Materi Power Point Siswa

\subsection{Implementation Model}

Implementation Model menampilkan hasil dari rancangan tampilan / userinterface yang dipadukan dengan source code PHP sehingga terbentuklah tampilan dari aplikasi media pembelajaran blended learning.

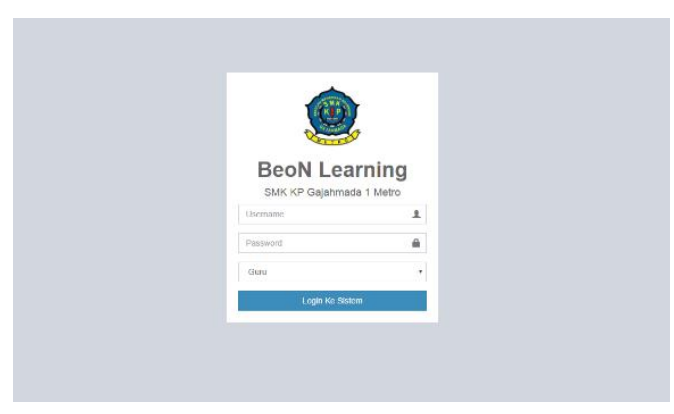

Tampilan Login

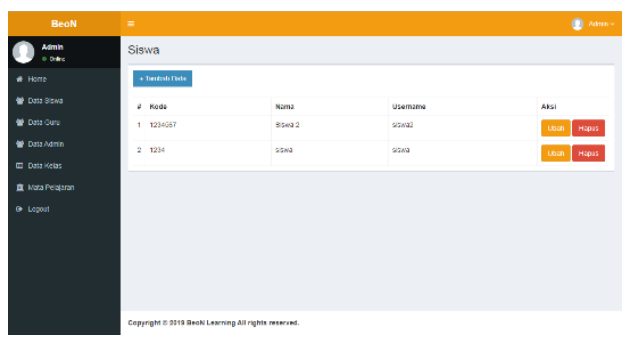

Tampilan List Siswa

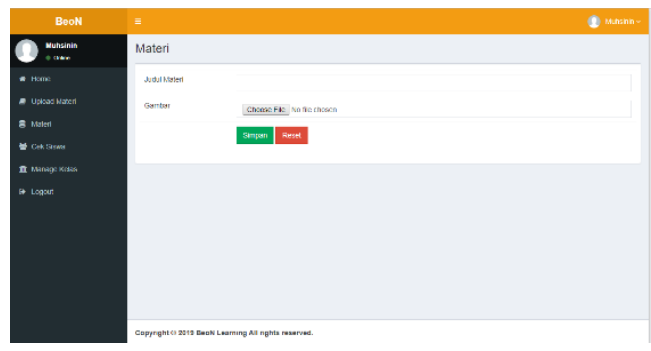

Tampilan Upload Materi

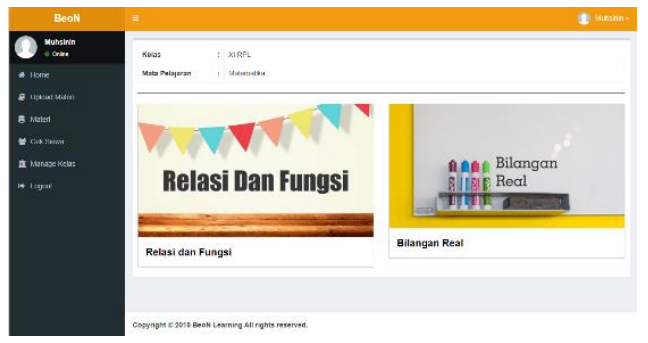

Tampilan Materi Utama

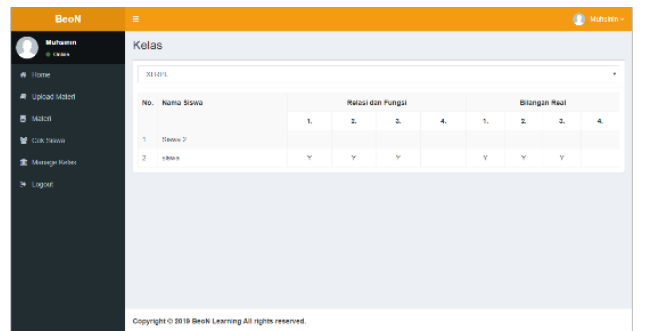

Tampilan Cek Progres Siswa 


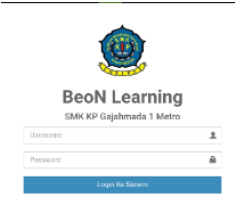

Tampilan Login Siswa

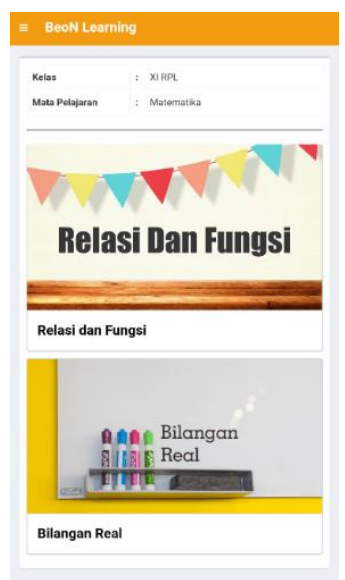

Tampilan Materi Utama Siswa

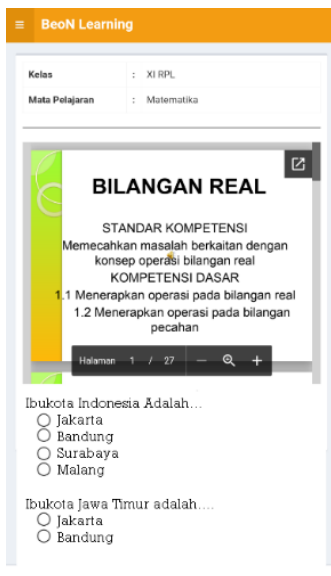

Tampilan Materi Power Point Siswa

\section{HASIL DAN PEMBAHASAN}

Aplikasi media pembelajaran Blended Learning SMK KP Gajahmada 1 Metro dibuat untuk memudahkan proses pembelajaran guru dan siswa, cara menggunakan tinggal login yang sudah didaftarkan oleh admin untuk mengakses aplikasi browser web untuk user guru dengan mengakses url : http/beonlearninggama.xyz sedangkan untuk user siswa terdapat aplikasi pada smartphone untuk login ke aplikasi . User dapat dengan mudah menggunakan untuk kepentingan masing-masing.

Berikut ini fasilitas-fasilitas yang disediakan pada aplikasi media pembelajaran blended learningseoerti terlihat pada gambar tampilan dibawah ini:

a. Aplikasi blended learning dapat mempermudah pembagian materi ke seluruh siswa di sekolah maupun di luar jam sekolah.

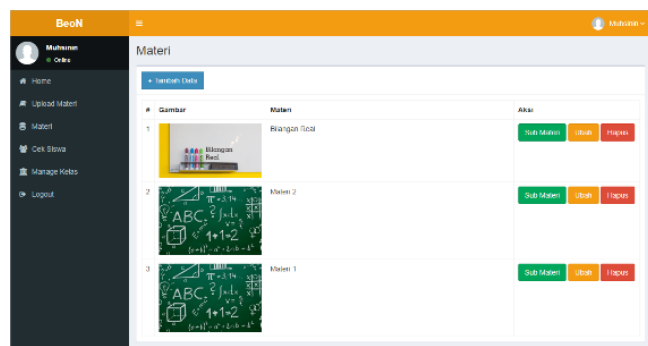

b. Aplikasi blended learning dapat mempermudah dalam penyampaian materi yang membutuhkan praktik secara langsung melalui video simulasi

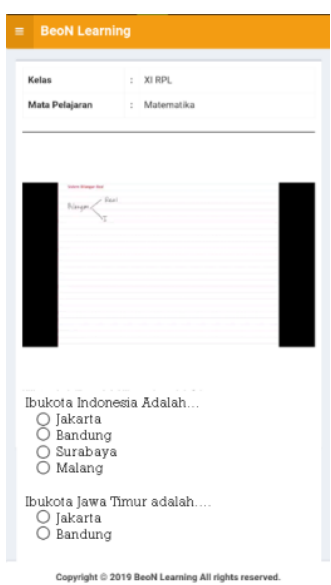

c. Aplikasi blended learning menyediakan forum diskusi antara siswa dan guru seputar kegiatan belajar mengajar di sekolah dan di luar jam sekolah. 


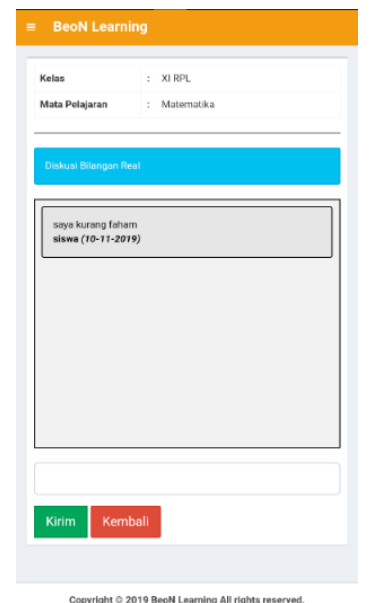

d. Aplikasi blended learning membuat guru dapat memonitoring progres belajar siswa.

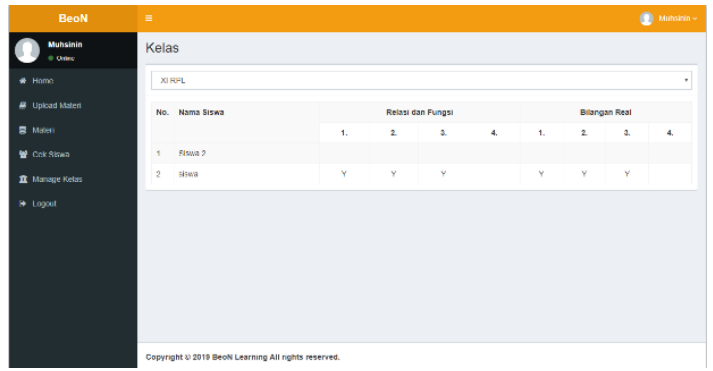

\section{KESIMPULAN}

Dari hasil pembahasan uraian diatas maka ditarik kesimpulan sebagai berikut :

Dengan adanya aplikasi media pembelajaran blended learning di SMK KP Gajahmada 1 Metro dapat menunjang proses pembelajaran antara guru dan siswa, membuat interaksi antara guru dan siswa lebih intesif sehingga diharapkan mampu meningkatkan minat belajar dan prestasi belajar siswa.

\section{DAFTAR PUSTAKA}

[1] Sutojo,T. dan Edy Mulyanto, Vincent Suhartono.2011. KECERDASAN BUATAN. Yogyakarta: ANDI Yogyakarta.

[2] Whitten, Jeffrey L. Lonnie D Bentley. 2007. Systems Analysis and Design Methods, $7^{\text {th }}$ Edition. New York: The McGraw-Hill Companies, Inc. New York.
[3] Pane, Aprida dan Muhammad Darwis Dasopang (2017).Belajar dan Pembelajaran. Jurnal Kajian Ilmu-ilmu Keislaman. IAIN Padang Sidimpuan. ISSN 2442-6997.

[4] Sudarman(2014). Pengaruh Stategi Pembelajaran Blended Learning Terhadap Perolehan Belajar Konsep dan Prosedur Pada Mahasiswa yang Memiliki Self-Regulated Learning Berbeda. Jurnal Pendidikan dan Pembelajaran. Universitas Mulawarman.

[5] Istiningsih, Siti. dan Hasbullah (2015). Blended Learning, Trend Stategi Pembelajaran Masa Depan. Jurnal Elemen. Universitas Mataram.

[6] Mukaromah, Siti dan Dadi Rosadi (2015). Perancangan Aplikasi E-Commerce (Studi Kasus : Distributor Coklat Bandung). Jurnal Computect \& Bisnis. STMIK Mardira Indonesia Bandung. ISSN 2442-4943.

[7] Mustaqbal, M. Sidi dan Roeri Firdaus, Hendra Rahmadi. 2015. Pengujian Aplikasi Menggunakan Black Box Testing Boundary Value Analysis (Studi Kasus: Aplkasi Prediksi Kelulusan SNMPTN). Jurnal Ilmiah Teknologi Informasi Terapan (JITTER). 1 (3)

[8] Setiawan, Ganang Wahyu. 2011. Pengujian Perangkat Lunak Menggunakan Metode Black Box Studi Kasus Exelsa Universitas Sanata Dharma. Skripsi. Program Studi Teknik Informatika Jurusan Teknik Informatika Fakultas Sains dan Teknologi Universitaas Sanata Dharma Yogyakarta.

[9] Hidayat, Didin. 2014. Membuat Aplikasi ELearning Pada Sekolah Menengah Pertama Negeri 30 Bandung. Skripsi. Program Studi Teknik Informatika Fakultas Teknik dan Ilmu Komputer Universitaas Komputer Indoensia.

[10] Harsono, Beni dan Soesanto, Samsudi (2009).Perbedan Hasil Belajar Antara Metode Ceramah Konvensional Dengan Ceramah Berbantuan Media Animasi Pada Pembelajaran Kompetensi Perakitan Dan Pemasangan. Jurnal PTM. Universitas Negeri Semarang.

[11] Achmadi, Taofan Ali. 2015. Pengaruh Penerapan Blended Learning Terhadap Prestasi Siswa Kelas XI Teknik Permesinan SMK Muhammadiyah 3 Yogyakarta. Skripsi. Jurusan Pendidikan Teknik Mesin Fakultas Teknik Universitas Negeri Yogyakarta. 